\title{
New Evidence on the Healthy Immigrant Effect
}

\author{
Lídia Farré* \\ Universitat de Barcelona (GiM-IREA), Institut d'Anàlisi Econòmica (IAE-CSIC) and IZA
}

\begin{abstract}
This paper presents new evidence that immigrants have better health than natives upon arrival to their destination. It analyzes a very interesting episode in international migration, namely the exodus of Ecuadorians in the aftermath of the economic collapse in the late 1990s. More than 600,000 Ecuadorians from 1999 to 2005 left their homeland, most relocating in Spain. Using information from the birth certificate data, the paper compares the birth outcomes of immigrant women in Spain not only to that of natives at destination, but to that of natives in Ecuador and immigrants from other nationalities in Spain. These comparisons suggest that the better health at birth of children born to immigrants from Ecuador partly responds to the selection of healthier women into migration.
\end{abstract}

JEL: J15, J61, I14

Keywords: Immigration, selection, health and birth outcomes

\footnotetext{
*University of Barcelona. Dep. of Economic Policy (GiM-IREA). Carrer Keynes 1-11, 08034, Barcelona. Email: lidia.farre@gmail.com. Telf: (+34) 934021869.
} 


\section{Introduction}

In migration research questions about the characteristics of those who migrate remain fundamental. To evaluate the costs and benefits of population movements, immigrants are compared to the native population at destination and in the source country along many dimensions (e.g. education, age, risk and entrepreneurial attitudes or health).

The health of immigrants is an issue of concern. Some critical voices argue that migration may represent a burden to the public health system financed mainly by natives at destination. The health of immigrants may also be a relevant factor for their assimilation and integration process. For the sending country, the characteristics of those who leave may as well have repercussions at the aggregate level, for example, in terms of health and inequality.

A widely known and established regularity is that new immigrants to developed countries such as the US, Canada, and Australia enjoy significant health advantages relative to comparable native born individuals in these countries. ${ }^{1}$ This is known in the literature as the healthy immigrant effect (HIE). The HIE is present among most immigrant groups, even though a vast majority come from developing countries with worse life expectancy indicators. There is also evidence that the health gap does not respond to socioeconomic differences in terms of education and income as most recent immigrants fall behind the native population in these dimensions.

Considerable attention has been directed to the puzzle of the health advantage of immigrants. In an expanding literature at least three alternative explanations have

\footnotetext{
${ }^{1}$ For the US see Jasso et al. 2004, Abraido-Lanza et al. 1999, Antecol and Bedard 2006, and Giuntella 2012. Chen et al. 1996, Deri 2003, McDonald 2003 and Laroche 2000 have documented a health advantage among immigrants to Canada, while Donovan et al. 1992, Chiswick et al. 2008, and Powles and Gifford 1990 do so for immigrants to Australia.
} 
sought to account for it. First, their better health may simply be a symptom of healthier diets, habits and behaviors inherited from the country of origin (i.e. the cultural hypothesis). Second, the migration episode may have a direct impact on health as a result of income shocks or other intense changes in life style directly related to the movement (i.e. the causal or direct effect of migration). Finally, it may be that only healthy individuals are ready to make their way to a remote and unfamiliar labor market. Consequently, individuals in the upper tail of the health distribution are more likely to migrate (i.e. the selective migration hypothesis). ${ }^{2}$

The aim of this paper is to better understand the channels behind the healthy immigrant effect. I study a very interesting episode in international migration, namely the Ecuadorian exodus in the aftermath of the economic collapse of the late 1990s. From 1999 to 2005 more than 600,000 Ecuadorians left their country, and most headed towards Spain rather than the US, the traditional destination for Ecuadorian migration (Bertoli et al. 2011).

The paper employs birth outcomes as a measure of maternal health (i.e. birth weight, low birth weight (less than 2,500 grams), gestational length, preterm birth (less than 38 weeks of gestation) and death within 24 hours of birth). Poor maternal health and risky behaviors during pregnancy have been shown to adversely affect birth outcomes. ${ }^{3}$ For example, nutritional deprivation and maternal stress during pregnancy lead to lower birth weight and reduce gestational length (Almond and Mazumder, 2013; Bozzoli and Quintana, 2014; Camacho 2008; and Quintana and

\footnotetext{
${ }^{2}$ It has also been suggested that the immigrant health advantage could derive from the mandatory health screening that is part of the migration process in some countries. However, some evidence indicates that admission policies are not the principal determinant of the health gap (Laroche, 2000 and Uitenbroek and Verhoeff, 2002).

${ }^{3}$ See Aizer and Currie (2014) for a detailed survey of the literature.
} 
Ródenas, 2014). Smoking also increases the probability of low birth weight (Currie, Neidell and Schmieder, 2009), while participation in supplemental nutritional programs reduces it (Hoynes, Page and Stevens, 2011). In addition, Currie and Moretti (2007) document an important intergenerational correlation in birth outcomes (i.e. low birth weight).

In the empirical analysis I employ administrative birth certificate data for Ecuador and Spain, which give coverage to all registered births in both countries. Since 2001 immigrants in Spain, independently of their legal status, have incentives to register to have access to the public health and education system. Thus the data contain information on illegal immigrants that is usually not available. In addition, administrative records not always contain information on years since arrival. Hence the focus on the Ecuadorian exodus represents a relevant contribution as it allows analyzing the determinants of the healthy immigrant effect net of assimilation or acculturation on a large number of recent immigrants. ${ }^{4}$

The paper documents an important advantage in terms of birth outcomes among immigrant women from Ecuador in Spain. These women also show better outcomes than their native counterparts in Ecuador, suggesting that healthier habits and behaviors inherited in the country of origin do not seem to be the only explanation for their health advantage. Finally, Ecuadorian immigrants are compared to those from Romania, another large minority group in Spain. The comparison reveals an important health advantage in favor of the former group. This last finding is consistent with the theoretical prediction that immigrants from more remote areas are more positively selected to compensate the higher cost of the move (Chiswick, 1999). This

\footnotetext{
${ }^{4}$ As a result of the exodus the Ecuadorian population in Spain increased from 76,000 individuals before 2000 to 457,000 in 2005 (Bertoli et al. 2011).
} 
is reassured when the comparison is extended to immigrants from Colombia, Bulgaria and China.

The results in this paper may have important implications for the socioeconomic outcomes of immigrants at destination. Birth weight and low birth weight have been shown to be important predictors of health later in life, including the probability of infant mortality (Almond et al. 2005). They are also strongly associated with long term outcomes, such as education, earnings, pregnancy complications and disability claims (Behrman and Rosenzweig 2004; Black, Devereux, and Salvanes 2007; Royer 2009 and Oreopoulos et al 2008). ${ }^{5}$ The better health at birth of children born to immigrant mothers could compensate the negative effects of other migration penalties related, for instance, to discrimination or the absence of assimilation (Bosch et al. 2010).

The paper is structured as follows: the next section briefly discusses the literature on the healthy immigrant effect, section III highlights the main features of the international migration episodes in this study; section IV describes the data; section $\mathrm{V}$ discusses the empirical methodology; the results and some robustness checks are presented in section VI and section VII concludes.

\footnotetext{
${ }^{5} \mathrm{An}$ important debate in this literature is the existence of nonlinearities in the effect of birth weight. For example, Almond et al. (2005) and Royer (2009) find that the relationship between birth weight and infant mortality is strongest for the lower birth weight births. Behrman and Rosenzweigen (2004) also find that augmenting birth weight among lower birth weight babies, but not among higher birth weight ones, has significant labor market payoffs. In contrast, they also find that increasing birth weight increases adult schooling attainment and adult height for babies at most levels of birth weight. Similarly, Black et al. (2007) find little evidence of significant nonlinearities in earnings, education, height or IQ tests. Finally, Royer (2009) shows that the effect of birth weight on education is strongest in the 2,500+ grams range, while Oreopoulos et al. (2008) find strong effects of birth weight on outcomes such as death between ages 1 and 17, grade completion, and months on social assistance after age 18, even for ranges not considered overtly concerning (for example, birth weights between 2,500 and 3,500 grams).
} 


\section{Literature Review}

Alternative explanations have been proposed to account for the health advantage observed among recent immigrants from developing countries. First, healthy diets, habits and behaviors in the home country lead to immigrants who are healthier than the average person in the recipient country. The hypothesis based on cultural differences is put forward in Abraido-Lanza et al. (1999). They argue that the lower mortality of Latinos in the US derive from more favorable health habits (i.e. less alcohol and cigarette consumption which are the major risk factors for cancer and heart diseases, the most common causes of death for both Lations and non-Latino Whites).

A second explanation is that the migration episode has a direct impact on an individual's health due to the resulting income shocks or environmental changes. Evidence on the causal impact of migration is sparse, mainly due to the methodological difficulties involved in estimation. An exception is the work by Stillman et al. (2012) that uses data from a unique survey. They compare the health of migrant children who entered New Zealand through a random ballot with children in the home country of Tonga whose families were unsuccessful participants in the same ballot process. Their findings indicate that migration increases height and reduces stunting of infants and toddlers, but also increases BMI and obesity among 3 to 5 years old. The authors argue that changes in dietary habits (i.e. increased consumption of meat, fat and milk) rather than the income gains associated to migration explain the findings.

Finally, the better health of recent immigrants could respond to selective migration. There are reasons to suspect that immigrants are different from those who do not migrate. The literature on selection, based on labor market outcomes (wages) 
and education, reports a large body of persuasive evidence pointing to positive selection (Chiquiar and Hanson 2005; McKenzie and Rapoport 2007, 2010; Orrenius and Zavodny 2005; Chiswick 1978, 1999; Belot and Hatton 2008; Grogger and Hanson 2008), though some evidence of negative selection has also been reported for Mexico (Borjas 1987; Fernández-Huertas Moraga 2011). If positive selection in productive skills dominates migration movements, given the strong correlation between income and health, positive selection in health should also be observed. Indeed, if immigrants are selected from the high end of the income distribution in their home countries, they are likely to have access to better diets, to cleaner water and sanitation, less exposure to environmental risks and superior child and maternal health care. Even in the absence of selective migration in skills positive selection in health is also expected. For example, if immigrants are forward looking (i.e. make current behavioral choices that emphasize future health at the expenses of current time/effort), or if sick individuals are more reluctant to leave the origin to make his or her way in an unfamiliar labor market. ${ }^{6}$

The large and diverse migration wave in Spain since the early 2000s is an interesting case study to analyze the alternative mechanisms behind the healthy immigrant effect. In this paper, the focus is mainly on the two largest recent minority groups: immigrants from Ecuador and Romania. Next I describe their migration experiences.

\footnotetext{
${ }^{6}$ Evidence of positive selection on health has been documented in Jasso et al. (2004) and Antecol and Bedard (2006).
} 


\section{Two large migration episodes}

Between 2000 and 2007, Spain received a remarkable inflow of immigrants - approximately 500,000 per year. The share of the foreign born population shifted from about 3 percent in the late 1990s to more than 10 percent by 2007. The composition of migrants changed over time. While in the 1990s migrants originated mainly from the EU-15 countries, they were rapidly overtaken by South Americans and migrants from the EU enlargement member states. The largest minority groups in Spain during the last decade were: Moroccans, Romanians and Ecuadorians. While the first group had a long tradition in the country, Romanians and Ecuadorians arrived massively only in the early 2000 s. $^{7}$

\section{The Ecuadorian Exodus}

Ecuador collapsed in 1999 as a result of the economic and financial crisis. This represented an important push factor for about 600,000 people (from a country with a population of 12.7 million) who over a few years (1999-2005) emigrated. A unique feature of this migration episode is that about 80-90 percent of these Ecuadorians went to the US and Spain, to the later roughly 3 times more than the former. Bertoli et al. $(2011,2013)$ argue that the lower cost of migrating explains the huge exodus towards the lower income country.

The migration policy in Spain was particularly attractive to Ecuadorians. Since 1963 a visa waiver program allowed them to enter as a tourist for a period of up to three months. Those who wished to migrate could simply overstay that time frame and become undocumented workers, and then legalize their status simply waiting for

\footnotetext{
${ }^{7}$ See Table $\mathrm{A} 1$ in the Appendix.
} 
one of the frequent amnesties in the early 2000s. ${ }^{8}$ The lax Spanish migration policy substantially influenced the location choices of immigrants. According to Bertoli et al. (2011) the Ecuadorian population in Spain increased from 76,000 individuals before 2000 to 457,000 in 2005. They represented 12 percent of immigration flows to Spain between 1999 and $2005 .^{9}$

The liberal visa waiver program was terminated in August 2003. Henceforth, Ecuadorian migrants needed a visa to enter any EU member state, so inflows to Spain immediately dropped sharply. The United States subsequently became their main destination (Bertoli et al. 2011).

A salient feature of the Ecuadorian exodus is that most of those who moved in the aftermath of the crisis headed towards Spain. Thus the analysis of birth outcomes in the early 2000s in Spain should be weakly affected by sorting across countries (i.e. migrants choosing their destination conditional on their health status).

\section{The Romanian Experience}

Prior to the collapse of the communist regime in 1989, very low number of immigrants were reported. They were mostly political refugees and/or relatively highly educated Romanians of another ethnicity (Jews, Germans and Hungarians). By the mid-1990s a new pattern of labor migration emerged, against the background of a slow pace of economic restructuring that resulted in an acute decline in GDP, high inflation, mass

\footnotetext{
${ }^{8}$ In the first half of the 2000s in Spain there were three amnesties to illegal immigrants (2001, 2002 and 2005).

${ }^{9}$ The same authors estimate that the Ecuadorian population in the US increased from 272,000 before 2000 to 394,000 in 2005, and represented 1.3 percent of immigration flows in the US during this period.
} 
layoffs, decreasing real wages and rising unemployment. ${ }^{10}$

The migration outflows sharply increased in 2001 when Schengen visa restrictions were lifted, allowing Romanians to freely circulate within the Schengen area. By 2010, Romanian immigrants were the most represented foreign group in both Spain and Italy. These two countries each hosted around 40 percent of Romanian immigrants in Europe, followed by Germany (5.72 percent), the UK (3.78 percent), Austria (2.23 percent), France (2.3 percent), Portugal (1.52 percent), Greece (1.73 percent) and Belgium (1.24 percent) (Andrén and Roman, 2014). It is important to note that while the Roma represented a large fraction of the immigrants in the 1990s, by the early 2000s their percentage had shrunk to that of the population in Romania (i.e. 5 to 10 percent). ${ }^{11}$

The international movements of Romanians can be classified in three groups (Ambrosini et al., 2012). A first one of strictly positive selected immigrants that move to traditional receiving countries such as the US, Canada and Australia. This flow is rather small but persistent and includes a significant share of young people who migrate for educational purposes. A second group of neutral average selected immigrants moved over the 1990s to several continental European countries: Germany, Austria and France. Finally, in the late 1990s and the early 2000s, large flows of Romanian migrants arrived to the Mediterranean countries, mainly Spain and Italy. Initially, those flows were characterized by negative selection but over time the pattern reversed and more skilled and educated Romanians relocated to Spain. ${ }^{12}$

\footnotetext{
${ }^{10}$ Deindustrialization led to a decrease of almost 3 million jobs in industrial employment that particularly impacted younger and older workers, who were less likely to find new employment opportunities (Voicu 2005).

${ }^{11}$ See Macias (2008).

${ }^{12}$ According to Fernández-Huertas Moraga (2013), between 2000 and 2007 a 5.1 percent of the population in Romania had a college degree, while this number was 9.5 percent among immigrants
} 


\section{Data}

The data in this paper are obtained from the birth certificates registered in Ecuador and Spain. In both countries, registration is the administrative procedure to legalize a vital event. ${ }^{13}$ Hence, the birth certificate data give coverage to all legalized births in those countries. Since 2001, the Spanish data collect information on immigrants irrespective of their legal status. A change in the law granted all registered individuals access to the public health and education system. This incentivized both legal and illegal immigrants to register their newborns who then appear in the official statistics. $^{14}$

The data for Ecuador and Spain contain information on birth weight and some socioeconomic characteristics of the mother such as age, province of residence, previous fertility and marital status. In Spain, the data also include detailed information on gestational length and death within 24 hours after birth. ${ }^{15}$

Birth weight, the most common indicator of health at birth, is defined as the body weight of a baby measured within an hour of birth. While it may suffer from measurement error, it is immune to the biases inherent in self-reported health questions in other studies. A main problem with reported assessments of one's own health is that it depends on the respondent's reference group. If the group is not stated, comparisons across individuals become difficult (King et al. 2004). This is particularly relevant

\footnotetext{
in Spain.

${ }^{13}$ In order to register a birth, the parents or the legal representative of the child have to present a document with statistical information on the birth outcome (Informe Estadístico del Nacido Vivo in Ecuador, or Boletín Estadístico del Parto in Spain).

${ }^{14}$ The Spanish data protection policy prevents the police from accessing the local population registry to identify illegal aliens.

${ }^{15}$ Unfortunately the birth certificates do not contain information on prenatal care.
} 
for immigrants whose comparison group may change over the course of assimilation. The use of the prevalence rate of some diseases (i.e. diabetes, cardiovascular and lung diseases) is also subject to legitimate methodological criticism, inasmuch as the lower incidence of such chronic diseases for foreigners may simply result from their less frequent contact with western medical diagnostics.

This paper employs the information available in the birth certificates to measure health at birth. That is, birth weight and low birth weight (less than 2,500 grams), as well as gestational length, preterm birth (less than 38 weeks of gestation), normal term birth (between week 38 and 42 weeks of gestation) and death within 24 hours after birth.

The analysis is restricted to the first half of the 2000s (i.e. 2001-2005). There are two main reasons that justify this constraint. First, since the official statistics do not contain information on years since arrival, it is not possible to account for the effect of acculturation and assimilation on birth outcomes. The inflow of Ecuadorians to Spain started in 1999 and was substantially interrupted after August 2003, when the visa waiver program terminated. Immigrants from Romania started to arrive in large numbers after 2001 when the Schengen visa restrictions were lifted. The inflow slowed down in $2005 .{ }^{16}$ Hence restricting the analysis to the first half of the 2000s guarantees that the majority of births to Ecuadorians and Romanians are to recent immigrants. Second, illegal immigrants have incentives to register their children (and thus appear in the official statistics) only after the approval of the new immigration law in 2000 .

Table 1 shows the percentage of births in Spain during the 2000s by nationality.

\footnotetext{
${ }^{16}$ See Table A1 in the Appendix.
} 
The effect of the large immigration inflow is clear. From 2001 to 2008 (the first year of the Spanish economic recession) the number of total births increased from 406,380 to 519,779 of which births to foreign mothers more than doubled, from 8.24 to 20.81 percent. The impact of the Ecuadorian exodus is documented in the fact that the number of births to Ecuadorian mothers doubled between 2001 and 2004 (from 5,649 to 11,092$)$, by 2004 representing 2.44 percent of total births. The table also shows the increase in the birth rate to Romanian immigrants, the largest minority group in Spain in the late 2000s.

"Insert Table 1 here"

Table 2 displays the average of several birth outcomes by nationality over the period 2001-2005 in Spain. ${ }^{17}$ Following previous literature, I focus on mothers aged 15-49, excluding multiple births and those newborns whose weight was either under 500 or above 9,000 grams. ${ }^{18}$ The table indicates that newborns of immigrant mothers are about 70 grams heavier than those of natives. Ranked by foreign nationality, the heaviest babies are born to Ecuadorians (3,295 grams) and then Romanians (3,237 grams), which is inconsistent with the aggregate health statistics in the origin countries (see Table A2). Accordingly, babies born in Romania are heavier than those born in Ecuador (3,196 grams versus 3,093 grams). However, the incidence of low birth weight is higher in Romania than in Ecuador and the birth weight distribution in Romania is more disperse (a standard deviation of 534 grams versus 470 grams). The descriptive statistics do not reveal significant differences in terms of

\footnotetext{
${ }^{17}$ The birth certificate data for Spain are made publicly available by the National Statistical Institute (INE).

${ }^{18}$ The descriptive statistics in Table 2 consider only the nationality of the mother. In estimation, I will take into account the nationality of the father.
} 
gestational length across groups, although immigrants from Romania show a higher rate of preterm births. Death within 24 hours after birth is the only measure for which immigrants perform worse than natives.

\section{"Insert Table 2 here"}

The birth certificate data for Ecuador are summarized in Table $3 .{ }^{19}$ The table compares the pregnancy outcomes of natives in Ecuador to that of Ecuadorian immigrants in Spain in the first half of the 2000s. ${ }^{20}$ I restrict the analysis to birth weight and low birth weight as information on gestational length is heavily underrerpoted in the Ecuadorian data. ${ }^{21}$ Information to construct the death within 24 hours of birth indicator is also not available.

\section{"Insert Table 3 here"}

The incidence of nonreported birth weight in the Ecuadorian data was substantial in the early 2000s. This rate was unevenly distributed across different groups. According to Table A3, non reporting between 2001 and 2005 was less than 25 percent among mothers with more than primary education and for births in hospitals. This rate was also much lower in urban than rural areas. Due to the incidence of nonreporting, the information on birth weights collected in the birth certificate data is unlikely to be representative of the whole Ecuadorian population: mothers with more than primary education, and middle/high-income groups living in urban areas

\footnotetext{
${ }^{19}$ These data are available from the Instituto Nacional de Estadística y Censos (INEC) in Ecuador.

${ }^{20}$ Note that the information for Ecuadorian immigrants in Spain is taken from the Spanish birth certificate data.

${ }^{21}$ Only 40 percent of the observations with valid information on birth weight report gestational length.
} 
are likely to be overrepresented. While this may represent a limitation for the analysis, the validity of the results is nevertheless reassured when looking closely at the characteristics of migrants. Bertoli (2010) documents that the wave of Ecuadorian migration who relocated in the aftermath of the crisis largely came from the urban areas. Cities were more severely hit due to the suspension of the wage payment to public employees and slash in real wages due to devaluation. In addition, it has been persuasively argued that in the early stage of the migration process it is the middle class that has the means and incentives to migrate (McKenzie and Rapoport 2007). Hence, the group of natives in Ecuador for whom there is valid information on birth weights in the early 2000s is likely to be closer to the immigrants to Spain than the Ecuadorian population as a whole. This factor is a counterbalance and will limit the magnitude of the bias due to differences in the composition of the comparison group. Section VI discusses the implications of this data problem for my results.

The paper employs two additional data sets. The Spanish Labor Force Survey for the years 2001-2005 (Encuesta de Población Activa, EPA) is used to investigate the fertility patterns and socioeconomic characteristics of different ethnic groups. This survey includes household level information on the socioeconomic characteristics of family members, with particular attention to their labor market status. The second data set is the National Immigrant Survey conducted in 2007 by the Statistical Office in Spain (Encuesta Nacional de Inmigrantes, ENI 2007) which analyzes the characteristics of the large inflow of immigrants to Spain. It covers the entire country and all immigrant groups, aiming to capture their demographic and social characteristics as well as their migration itineraries, work and residential histories. 


\section{Empirical methodology}

The first step in the empirical strategy is to assess the magnitude of the healthy immigrant effect. Hence I estimate the following model:

$$
\text { health }_{i}=\alpha+\beta^{H I E} I_{1 i}+u_{i}
$$

where the dependent variable, healt $h_{i}$, is the birth outcome of the child born to mother $i$ (i.e. birth weight, low birth weight, gestational length, preterm birth, normal term birth or death within 24 hours of birth). $I_{1 i}$ is an indicator variable that equals 1 if mother $i$ is an immigrant and 0 otherwise and $u_{i}$ is an error term. The OLS estimate of $\beta^{H I E}$ in equation (1) is obtained from the comparison of the birth outcomes of natives and those of Ecuadorian immigrants in Spain. It can be interpreted as the healthy immigrant effect.

Differences in birth outcomes between natives and immigrants may result from the healthier habits and behaviors of immigrant mothers acquired in the source country $\left(\beta^{\text {habits }}\right)$, the existence of a causal or direct effect of migration on a mother's health and that of her baby $\left(\beta^{\text {migration }}\right)$ or from the selective migration of healthier women that give birth to healthier children $\left(\beta^{\text {selection }}\right)$. That is:

$$
\beta^{H I E}=\beta^{\text {habits }}+\beta^{\text {selection }}+\beta^{\text {migration }}
$$

If healthy habits are common to individuals originating from the same country, the comparison of birth outcomes between immigrants at destination and natives in the source country produces a joint estimate of the effect of selection and of any causal 
effect of migration. ${ }^{22}$ The OLS estimate of this effect can be obtained from:

$$
\text { health }_{i}=\alpha+\delta I_{2 i}+u_{i}
$$

where $\delta=\left(\beta^{\text {selection }}+\beta^{\text {migration }}\right)$ and $I_{2 i}$ is equal to 1 if mother $i$ is an immigrant in Spain and 0 if $i$ is a native in Ecuador.

Ideally, to disentangle the contribution of selective migration from that of any direct or causal impact of migration, one would compare the health distribution of recent immigrants to their distribution had they not migrated (i.e. counterfactual distribution). This would identify the direct effect of migration (i.e. $\beta^{\text {migration }}$ ). Alternatively, the contribution of selective migration can be assessed by comparing immigrants and natives in the sending country before the movement occurs (i.e. $\beta^{\text {selection }}$ ). However, experimental data that randomizes the decision to migrate and allows estimating counterfactual distributions, or panel data that identifies immigrants before the movement occurs are rather scarce (see McKenzie et al. 2010 or Rubalcava et al. 2008 for exceptions). This paper takes an alternative approach and employs administrative data on birth outcomes to test a prediction of the migration model by Chiswick (1999) regarding the process that determines selection. The model states that the favorable selectivity of immigrants increases with the out-of-pocket (direct) cost of migration. Since this cost increases with distance to destination, immigrants from more remote areas are expected to be more positively selected than those originating from neighboring ones.

\footnotetext{
${ }^{22}$ Note that healthy habits may vary across individuals from the same sending country (e.g. different rates of prenatal care or nutrition). Differences among immigrants and non immigrants in this dimension will be captured by the selection $\left(\beta^{\text {selection }}\right)$ rather than the habits component $\left(\beta^{\text {habits }}\right)$.
} 
The large and diverse migration wave to Spain during the last decade offers an excellent scenario to assess the contribution of selective migration to the healthy immigrant effect. Since the early 2000s immigrants from many diverse origins landed in Spain, mostly attracted by a growing economy and job opportunities, especially in the construction sector. The empirical exercise in the next section will compare the birth outcomes of two of the largest ethnic minorities that have recently arrived in Spain from very different geographical regions: Ecuador and Romania. In the robustness checks the comparison is extended to Colombian, Bulgarian and Chinese immigrants.

Table 4 summarizes the economic costs of moving to Spain from different countries over the period 1999-2007. This information is collected from the National Immigrant Survey conducted in 2007. The survey interviewed immigrants along many dimensions. They were asked to delineate all the costs associated with their reallocation from their country of origin. These costs were not narrowly restricted to transport expenditures such as air fares or train tickets, but encompassed all types of expenses such as food, accommodation, the cost of obtaining a visa or other legal document, and any other expenses incurred before or during the migration episode. Table 4 shows that the cost of migrating from Ecuador to Spain was 3.5 more than moving from Romania (i.e. 1,609.72 Euros from Ecuador and 464.95 Euros from Romania).

\section{"Insert Table 4 here"}

The empirical strategy to identify selection based on the comparison of groups from different destinations relies on some assumptions. First, the distribution of birth outcomes should be identical across sending countries. Table A2 shows that this is not the case for the countries under study. For example, the average birth weight in 
Romania is larger than in Ecuador. Hence in the absence of selection, children born to Romanian immigrants will be heavier than those born to immigrants from Ecuador. The second assumption is that the returns to migration should be homogenous across groups. Accordingly, immigrants from different source countries are drawn from the same part of the ability or skill distribution. While this assumption is difficult to test, previous studies have documented that immigrants from Romania belong to the upper tail of the skill/education distribution and that this is not the case for Ecuador. ${ }^{23}$ Given the positive association between income (education) and health, better birth outcomes should be expected among immigrants from Romania. Third, one needs to assume that the cost of migrating is solely determined by distance to destination. However, cultural and linguistic barriers are likely to affect both migration costs and returns. In the case of Ecuador, the cultural and linguistic proximity may compensate the higher economic cost of the trip and reduce immigrant positive selection. But even if these barriers do not affect selection patterns, immigrants from Romania may have a harder time in understanding instructions from doctors or processing some relevant information upon arrival to the country. ${ }^{24}$ This could negatively affect their birth outcomes. Finally, the model in equation (1) assumes that the causal effect of migration is homogeneous. However this assumption fails if, for example, the size of changes in dietary habits or income shocks associated to the movement varies across groups. The implications of these assumptions will be discussed in the next section.

In estimation, the models in equation (1) and (2) are extended to control for differences between natives and immigrants that may have a direct impact on birth

\footnotetext{
${ }^{23}$ See Fernández-Huertas Moraga (2013) and Bertoli et al (2013).

${ }^{24}$ While the lexical similarity between Romanian and Spanish has been estimated at 71 percent, some immigrants upon arrival my not properly understand the native language.
} 
outcomes. First, immigrants tend to be positively selected in terms of education and productive skills. The health economics literature has established a strong relationship between parental education and a child's health (Currie 2009). Hence, positive selection in education could lead to better birth outcomes among immigrants. Unfortunately, the Spanish birth certificate data did not collect information on maternal education prior to 2007. For the years in the analysis, I can only control for differences in productive skills by including in the regression the mother's labor market status and an indicator for being employed in a high skilled occupation. Since these variables are not perfect proxies for educational achievement, the estimate of the health gap could still be biased. However, Bertoli et al (2011) find some evidence of negative selection in terms of the education among Ecuadorian immigrants in Spain. Thus, the omission of maternal education should produce, if any, a negative bias on the estimated health gap in equation (1).

Differences in family size may also be relevant for birth outcomes. The child quality investment model (Becker 1981 and Chiswick 1988) predicts that, at any given level of family resources, more children imply smaller levels of investment per child, and thus lower quality. In estimation I control for the presence and number of previous children, and a variable that captures the effect of birth spacing. ${ }^{25}$ Finally, it has been documented that parental income affects child's health (Currie and Moretti 2007). The birth certificates do not contain information on family income or wealth. As a proxy for the level of economic resources the empirical models include an indicator for the marital status of the mother and another for being born at a hospital.

\footnotetext{
${ }^{25}$ Differences in fertility patterns across groups and their implications for the results are investigated in the next section.
} 


\section{Results}

\section{The Healthy Immigrant Effect}

\section{a) Comparison to natives in Spain}

The estimate of the healthy immigrant effect is obtained from the model in equation (1), where the birth outcomes of children born to Ecuadorian mothers in Spain are compared to that of natives in Spain for the years 2001-2005. In terms of birth weight, the estimated coefficient, $\beta^{H I E}$, indicates an advantage in favor of immigrant children of 100.39 grams, with a standard deviation of $2.44 .^{26}$

As discussed the estimated health gap may respond to differences in some characteristics between natives and immigrants. Thus the model in equation (1) is extended to include a set of additional controls: the work status of the mother, an indicator for being employed in a high skilled occupation, variables to capture the presence and number of previous children, a measure of birth spacing, an indicator for being married and one for being born at a hospital. Table 5 presents the estimates of the extended model. The first column indicates a weight advantage in favor of immigrants of 117.68 grams, with a standard deviation of 4.91. The variables capturing the economic situation of the family (being born in a hospital, married, mother's employment status and working in a high skilled occupation) all have a positive effect. The coefficients on the variables related to family size are also positive. There is also evidence of a negative effect due to birth spacing. ${ }^{27}$

\footnotetext{
${ }^{26}$ The estimate is obtained by including as additional controls in equation (1) the gender of the child, an indicator for the month and year of birth, a set of dummies for the mother's age at the date of birth, as well as indicators for the province of residence in Spain.

${ }^{27}$ I replicate the results in Table 5 but excluding from estimation mixed couples (i.e. babies born to mothers from Ecuador and fathers from Spain, and that born to mothers from Spain and fathers from other nationalities). The main conclusions in Table 5 remain unaffected. The largest difference
} 


\section{"Insert Table 5 here"}

The remaining columns examine the presence of the healthy immigrant effect in terms of other birth outcomes: low birth weight (column 2), number of gestational weeks (column 3), preterm birth (column 4), born between week 38 and 42 (column 5), and death within the first 24 hours after birth (column 6). ${ }^{28}$ The estimates indicate a statistically significant health advantage in favor of Ecuadorian immigrants in most outcomes: the incidence of low birth weight (i.e. 2.2 percentage points lower probability), gestational length (i.e. 0.038 additional weeks of gestation), the probability of being born between week 38 and 42 (i.e. 1 percentage point higher) and the probability of preterm birth (i.e. 1 percentage point lower). No differences are observed in the probability of dying 24 hours after birth. ${ }^{29}$

The results in Table 5 may be affected by different fertility behaviors between natives and immigrants. To investigate this possibility I estimate the following model:

$$
\text { infant }_{i}=\beta_{0}+\beta_{1} I_{1 i}+u_{i}
$$

where the dependent variable, infant $i$, is an indicator for the presence of a child

appears in terms of birth weight: when mixed couples are excluded the estimated healthy immigrant effect is reduced by 10 grams. The results when mixed couples are excluded are available upon request from the author.

${ }^{28}$ Birth weight can be an inaccurate measure of maternal health as in some cases health problems of the mother, like diabetes, lead to an elevated weight of the baby. Therefore, I extend the analysis to these other pregnancy outcomes that are also related to maternal health (see Aizer and Currie 2014).

${ }^{29}$ Differences in birth weight and the probability of low birth weight between natives and immigrants could result from the observed differences in gestational length. To examine this possibility I have re-estimated the birth weight and the low birth weight regressions in column (1) and (2) in Table 5 including as an additional control gestational length. This slightly reduces the size of the healthy immigrant effect (from 117.7 grams to 110.1 grams in the birth weight regression and from -0.022 to -0.019 in the probability of low birth weight). These differences are still significant at any conventional level. 
younger than 1 year old. The indicator variable $I_{1 i}$ takes value 1 if observation $i$ corresponds to an immigrant from Ecuador and 0 otherwise. ${ }^{30}$

Equation (3) is estimated on the sample of 15-49 aged women in the Spanish Labor Force Survey for the years 2001 to 2005. Column (1) in Table 6 reveals a higher probability of having children among immigrants from Ecuador during the period under study. Column (2) extends the model to include a set of observable characteristics available in the Labor Force Survey that may affect fertility decisions, such as the years since arrival in the country, marital status, number of previous children and an indicator of whether the mother works. In this case, the difference in the propensity to have children disappears. The estimates in Table 6 highlight the importance of controlling for the labor supply and the fertility history of women when comparing their birth outcomes. ${ }^{31}$

\section{"Insert Table 6 here"}

On the whole, the results in this section strongly support the view that recent immigrant women from Ecuador in Spain have better birth outcomes than natives. ${ }^{32}$ These findings are consistent with the extensive evidence on the healthy immigrant effect that is well documented for Mexican immigrants in the US and other minority groups in Canada and Australia. ${ }^{33}$

\footnotetext{
${ }^{30}$ The model also includes a set of dummies for the age of the mother, as well as province and year indicators.

${ }^{31}$ Note that the estimated models in Table 5 include these controls.

${ }^{32}$ Note that the estimates in Table 5 are obtained from the births occurred between 2001 and 2005. Given the characteristics of the Ecuadorian exodus, most of these births are likely to be to recent immigrants or immigrants that have been in the country for less than 5 years. However, this assumption cannot be tested as information on year since arrival is not available in the data. There is evidence, mostly among Mexican immigrants in the US (see Antecol and Bedard, 2006) showing that the initial health advantage erodes over time as immigrants assimilates. If this pattern also existed among Ecuadorian immigrants in Spain (data limitation issues prevent me from testing it), the estimates in Table 5 would represent a lower bound of the healthy immigrant effect.

${ }^{33}$ As discussed in Section IV the analysis is restricted to the years 2001-2005 (i.e. pre-crisis period).
} 


\section{b) Comparison to natives in Ecuador}

While the previous estimates reveal a clear advantage in terms of birth outcomes in favor of immigrants, they are not informative about the channels behind it. I next estimate the model in equation (2) where the birth outcomes of Ecuadorian mothers in Spain are compared to that of natives in Ecuador. This comparison produces a joint estimate of the effect of selection and of any causal effect of migration. Table 7 shows the OLS estimates of equation (2) including as additional controls those common to the birth certificates in the two countries, namely the child's gender, the mother's age, the month and year of birth, those related to fertility histories (i.e. the presence and number of previous children) and whether the child was born at a hospital. The analysis is restricted to the comparisons of birth weights and the incidence of low birth weight. ${ }^{34}$

\section{"Insert Table 7 here"}

The estimates indicate that newborns to Ecuadorian immigrants in Spain are 178.68 grams heavier than those born to natives in Ecuador, with a standard deviation of 2.09. The probability of low birth weight is also 2 percentage points lower among immigrants. If healthier practices and behaviors were the only responsible for the advantage of immigrants in Spain, we should not observe differences in birth outcomes when compared to the native population in Ecuador. Hence, the large size of the

Fernández-Huertas Moraga (2014) shows that migration flows to Spain were positively selected in terms of productive skills during the booming years, and that, on average, they improved after the crisis. However, for the Ecuadorian case, there is evidence of negative selection in terms of some education measures after the crisis. This suggests that my estimates of the healthy immigrant effect for the period 2001-2005 may be positively biased as a result of the different selection patterns over the business cycle.

${ }^{34}$ Gestational age is only reported for $40 \%$ of the births with valid information on weight and there is no information to construct the death within 24 hours after birth. 
estimated coefficients in Table 7 indicates that factors other than cultural traits are driving the healthy immigrant effect.

Two issues should be taken into account when analyzing the results in Table 7. First, Ecuador was immersed in a major economic recession in the early 2000s, which may have had a negative effect on birth outcomes. Indeed, Bozzoli and Quintana (2014) document the existence of procyclicality in birth weights for Argentina. Second, a non-negligible fraction of the observations in the Ecuadorian birth certificates do not report information on birth weights in the early 2000s. As discussed, nonreporting is less severe among high-income and more educated mothers. This should tend to bias Ecuadorian babies' weight upwards. Table 8 investigates the implications of these two concerns by comparing the estimates of the birth weight gap on different samples. Column (1) shows the estimated gap between immigrants and natives for the years 2001-2005 as in Table 7, but without including year fixed effects. In column (2) the gap is estimated from comparing the birth weight of immigrants in 2001-2005 to those of natives in 2006-2010, when the Ecuadorian crisis was over and the incidence of non-reporting much lower (see Table A3). Note that the estimated gap decreases from 179.13 to 166.53 suggesting that part of it could reflect bad outcomes in Ecuador during the bust. Column (3) and (4) repeat the same exercise for the probability of low birth weight. In this case, the gap slightly increases. However, the magnitude of these differences (both in terms of birth weight and the probability of low birth weight) is very small and indicates that the timing of the comparison group is not the main force driving the results.

\section{"Insert Table 8 here"}




\section{c) Comparison to other immigrant groups}

Next I investigate whether the more favorable birth outcomes among immigrant women from Ecuador could be explain by positive selection. A prediction of the migration model is that immigrant selectivity should increase with distance to destination. This section compares the birth outcomes of two minority groups in Spain, immigrants from Ecuador and Romania, who are similar along many dimensions but their geographical origin. First, the two groups face relatively low cultural and linguistic barriers (i.e. Spanish is the language of Ecuador and Romanian is a Romance language very close to Spanish $\left.{ }^{35}\right)$. Second, the bulk of Ecuadorians and Romanians arrived between 2000 and $2004 .{ }^{36}$ Third, the two groups moved to Spain for economic reasons. Ecuadorians came escaping from the economic and financial collapse in 1999, while immigrants from Romania arrived looking for jobs, running away from the high unemployment rates that followed the massive restructuring of state enterprises in the late 1990s. Finally, Table A4 in the Appendix shows that Romanian and Ecuadorian immigrants to Spain are similar in terms of education and work status. The main difference is observed in terms of fertility outcomes. Only 45 percent of the Romanian females have children, as opposed to 70 percent of the Ecuadorians, and their average number of kids is 1.33 and 1.67 respectively. I investigate the implications of these differences in fertility for my results.

Table 9 presents the estimates of the model that compares the birth outcomes of immigrants from Ecuador and Romania. There is a clear advantage in favor of Ecuadorians. These women give birth to children that are 60 grams heavier than

\footnotetext{
${ }^{35}$ The lexical similarity of Romanian with Spanish has been estimated at 71 percent.

${ }^{36}$ Table A1 in the Appendix indicates that among the Ecuadorian and Romanian immigrants living in Spain in 2007, 72 percent of them arrived between 2000 and 2004.
} 
those born to immigrants from Romania, have a smaller probability of low birth weight (2.8 percentage points lower), longer gestational age ( 0.20 weeks), a higher probability of being born between week 38 and 42 (4.1 percentage points higher), a lower incidence of preterm birth (4 percentage points lower) and a lower probability of death within the 24 hours after birth (0.1 percentage points). ${ }^{37}$ These estimates are all statistically significant at any conventional level. ${ }^{38}$

\section{"Insert Table 9 here"}

While the results are consistent with the prediction that the positive selection of immigrants increases with distance to destination (Chiswick, 1999), alternative explanations could also account for the better birth outcomes of immigrants from Ecuador. First, cultural and linguistic barriers may affect the costs and returns of migration. Hence the advantage of Ecuadorians could lead to less positively selected immigrants. On the other hand, the linguistic disadvantage of Romanians may negatively affect their pregnancy outcomes if they have difficulties in understanding medical instructions or gathering other relevant information. Hence the effect of cultural proximity on the estimates in Table 9 is ambiguous.

Second, different selection patterns in terms of productive skills could also drive the results. However, the existing evidence suggests that immigrants from Romania are positively selected in terms of education while this is not the case for immigrants from Ecuador (Fernández-Huertas Moraga, 2013). Given the positive association between income (education) and health, this would tend to attenuate the health advantage in favor of Ecuadorian immigrants.

\footnotetext{
${ }^{37}$ These results are obtained after controlling for differences in socioeconomic characteristics. A similar message is obtained when the models are estimated without including the additional controls.

${ }^{38}$ Note that the health advantage in terms of birth weight is present even if the average birth weight in Romania is higher than in Ecuador (i.e. 3,196 versus 3,098).
} 
Finally, researchers have not been able to identify the causal effect of migration on pregnancy outcomes. The closest evidence is the paper by Stillman et al. (2012) who report evidence regarding the Tongan migrant lottery to explore the effect of migration on child health. They conclude that changes in dietary habits (i.e. larger consumption of meat, fat and milk) rather than income gains are behind the increase in height and BMI of immigrant children. While those changes in nutritional factors would almost certainly have a positive effect on birth weight, there may well be a wide range of countervailing effects that are not identified in Stillman et al. (2012), inasmuch as children in their sample are born before migration occurs. For example, the migration episode may be stressful (i.e. many social, cultural and economic changes are involved) and newcomers may face some post-migration practical living difficulties that may negatively affect birth outcomes. ${ }^{39}$ Thus the sign of the direct effect of migration and its possible heterogeneity across immigrant groups is difficult to gauge.

I also investigate whether the differences in birth outcomes are driven by different fertility behaviors. The estimates in Table 6 column (3) and (4) correspond to the model in equation (3) where the comparison group are immigrants from Romania. The first set of estimates indicate that immigrants from Ecuador are more likely to have children during the period 2001 to 2005, however this difference becomes statistically insignificant when previous children, work and marital status are included in estimation. Thus the better outcomes of Ecuadorian immigrants in Table 9 do not seem to respond to differences in fertility.

The previous results indicate a clear health advantage in favor of immigrants from

\footnotetext{
${ }^{39}$ See Camacho 2008; Almond and Mazumder, 2011; and Bozzoli and Quintana, 2014 for evidence of the negative effect of stress and malnutrition on birth outcomes.
} 
Ecuador. This is despite the presence of factors such as the worse health distribution (in terms of birth weight, Table A2) in Ecuador, the negative selection of Ecuadorian immigrants in education and productive skills, and their lower cultural and linguistic barriers. Therefore, while the contribution of selective migration can not be precisely estimated, the evidence here supports the view that immigrant women from more remote areas are more favorable selected in terms of health and give birth to healthier children upon arrival to destination.

The advantage estimated for immigrants from Ecuador would also be present in the absence of positive selection if, for instance, the migration episode had a very negative effect on the birth outcomes of immigrants from Romania or if the higher linguistic barriers badly affected their birth outcomes. While I cannot rule out the presence of these alternative channels, it is unlikely that they are the only responsible for the better health reported for Ecuadorians.

To further explore and verify the prediction that positive selection increases with geographical distance, I extend the comparison to other established ethnic minorities in Spain, namely Colombians and Bulgarians. During the early 2000s, Colombian immigrants were the third largest group after Moroccans and Ecuadorians. Bulgarians are a smaller but significant group; in 2004 they represented the eighth most popular non-EU15 immigrant-sending country and the second largest group among Eastern European immigrants in Spain.

Colombian emigration began in the 1960s in search of better economic opportunities. The US was the main destination for this first wave of immigrants. Typically these immigrants were not only well educated, but also highly competent in English. In the case of emigration to Spain, it increased considerably beginning in 1998, largely 
as a result of the Colombia's economic crisis (1998-1999). Spain's attraction was as a place in which to join the collective immigrant workforce, as well as the critical advantage of the language. A large percentage of Colombian migrants in Spain are women with a medium educational level (see Table A4). Ecuador and Colombia are neighboring countries and Table 4 indicates that the economic cost of migrating from either to Spain is similar.

Large-scale immigration from Romania and Bulgaria coincided with their inclusion in the list of countries exempted from the general visa requirements in early 2002 as a first step towards their membership of the EU. Both countries were by far the poorest of the 27 countries that would be part of the enlarged EU after January 2007, making emigration an attractive means of improving the prospects in life for both the emigrants themselves and for those staying behind. Table A4 in the Appendix shows that immigrants from Bulgaria and Romania in Spain are comparable in terms of socioeconomic characteristics. Bulgaria shares its northern border with Romania, hence the economic cost of migrating to Spain is similar and much lower than from Ecuador or Colombia (see Table 4).

Table 10 compares the birth outcomes of the different groups. In estimation the excluded category are immigrants from Ecuador. The comparison to immigrants from Colombia indicates a small, though statistically significant, disadvantage for this group in terms of gestational length. However, it does not translate into other birth outcomes. Indeed, differences between Colombian and Ecuadorian immigrants in terms of birth weight, the probability of low birth weight and that of dying before 24 hours are statistically insignificant. In contrast, children born to immigrants from Bulgaria are lighter than those born to Ecuadorian immigrants. ${ }^{40}$ The findings in

\footnotetext{
${ }^{40}$ Table A5 reports the estimates of the fertility model for these groups. Note that immigrants
} 
Table 10 provide additional evidence that immigrants from more remote areas are more favorable selected.

\section{"Insert Table 10 here"}

An interesting final comparison is that to immigrants from China. The Chinese community in Spain has a long tradition. As reported in Table A1, more than 50\% of the Chinese living in Spain in 2007 had arrived prior to 2000. Despite being a relatively small group, its size has grown sixfold over the last decade and represents the second largest non-EU15 and non-Spanish speaking group after Moroccans. As immigrants from Latin America, individuals originating from China have to afford important travel costs (see Table 4). Moreover they face large cultural and linguistic barriers that add an additional burden to the cost of migrating. As a result, the Chinese in Spain are expected to be more positively selected than the other groups.

Table 10 indicates that immigrants from China present a small advantage in terms of the incidence of low birth weight and gestational length when compared to immigrants from Ecuador and Colombia. The advantage becomes larger when the comparison is extended to the EU immigrant groups. Part of their better outcomes could respond to the lower fertility among Chinese immigrants (see Table A5). However, the evidence is also supportive of the prediction that immigrants from China are more favorable selected to compensate the higher monetary and non-monetary (cultural and linguistic) costs of the movement. ${ }^{41}$

from Colombia and Bulgaria have lower fertility rates than immigrants from Ecuador. Thus the health advantage of Ecuadorian immigrants does not respond to lower fertility.

${ }^{41}$ Note that Chinese immigrants have a long tradition in Spain. There is evidence that the initial health advantage of immigrants erodes over time as their practices and behaviors converge to that of natives (Antecol and Bedard 2006). Thus the healthy immigrant effect for the Chinese reported 


\section{Conclusions}

This paper presents new empirical evidence on the determinants of the health advantage observed among recent immigrants in developed countries. It focuses on a large migration inflow of Ecuadorians to Spain in the early 2000s. Using the official statistics on births taking place in both countries, it documents an important health advantage for immigrants in terms of birth outcomes (i.e. birth weight, low birth weight and gestational length). The comparison to other recent minorities in Spain suggests that the better outcomes of Ecuadorians partly result from the positive selection of immigrant mothers who give birth to healthier babies.

These findings have at least two important policy implications. First, the health advantage of immigrant children at birth may translate into an advantage in terms of education and earnings that may compensate some of the disruptive effects associated to migration (i.e. discrimination, lower economic resources or poorer network quality). Second, immigration is not likely to represent a financial burden for the public health system, as long as the health advantage of recent immigrants remains stable over time. An obvious avenue for future research is to examine the evolution of the health advantage uncovered among recent immigrants.

in Table 10 could be underestimated due to the presence of non-recent immigrants in the data. 


\section{Acknowledgements}

I am thankful to the editor, Klaus Zimmermann, and three anonymous referees for their comments, help and guidance. I also acknowledge the comments and suggestions by Jesús Fernández-Huertas Moraga, Hillel Rapoport, Deborah Cobb-Clark, Matilde Machado, Libertad González, Alessia Matano and participants at the $10^{\text {th }}$ IZA Annual Migration Meeting and $4^{\text {th }}$ Migration Topic Week, the $15^{\text {th }}$ IZA/CEPR European Summer Symposium in Labor Economics and the $14^{\text {th }}$ IZA/SOLE Transatlantic Meetings of Labor Economists for comments and suggestions. I acknowledge the financial support of the Government of Catalonia (grant SGR2014-325), the Ministry of Economy and Competitiveness (grant ECO2014-59959-P-P) and the RecerCaixa 2012 grant. 


\section{References}

[1] Aizer A and Currie J (2014) The intergenerational transmission of inequality: Maternal disadvantage and health at birth Science 344:856-861.

[2] Abraido-Lanza A, Dohrenwend B, Ng-Mak D and Tuner J (1999) The Latino mortality paradox: a test of the "salmon-bias" and healthy migrant hypothesis Am J Public Health 89:1543-48.

[3] Almond D, Chay K, and Lee D (2005) The costs of low birth weight Q J Econ 120(3): 1031-1083.

[4] Almond D and Mazumder B (2013) Health capital and the prenatal environment: the effect of maternal fasting during pregnancy American Economic Journal: Applied Economics 3(4): 56-85

[5] Ambrosini JW, Mayr K, Peri G and Radu D (2012) The selection of migrants and returnees in Romania: Evidence and long-run implications. IZA Discussion Papers No. 6664, IZA Bonn.

[6] Andrén A and Roman M (2014) Should I stay or should I go? Romanian migrants during transition and enlargement. IZA Discussion Papers No. 8690, IZA Bonn.

[7] Antecol H and Bedard K (2006) Unhealthy Assimilation: do Immigrants Converge to American Weights? Demography 43(2):337-360.

[8] Anuario de Nacimientos. Ecuador. Several years. http://www.inec.gob.ec/estadisticas/?option=com_content\&view=article\&id=114\&Itemid=91

[9] Becker G (1981) A treatise on the family Cambridge, Mass: Harvard University Press.

[10] Behrman J and Rosenzweig MR (2004) Returns to Birthweight Rev Econ Stat 86(2): 586-601.

[11] Belot MV and Hatton TJ (2008) Immigrant Selection in the OECD. Australian National University Centre for Economic Policy Research discussion paper 571.

[12] Bertoli S (2010) Networks, sorting and self-selection of Ecuadorian Migrants Ann Econ Stat 97/98: 261-288.

[13] Bertoli S, Fernández-Huertas Moraga J and Ortega F (2011) Immigration Policies and The Ecuadorian Exodus World Bank Econ Rev 25(1):57-76. 
[14] Bertoli S, Fernández-Huertas Moraga J and Ortega F (2013) Crossing the Border: Self-selection, Earnings, and Individual Migration Decisions J Dev Econ 101:7591.

[15] Black S, Devereux PJ and Salvanes K (2007) From the Cradle to the Labor Market? The Effect of Birth Weight on Adult Outcomes Q J Econ 122(1): 409439.

[16] Borjas G (1987) Self-Selection and the Earnings of Immigrants Am Econ Rev 77(4): 531-553.

[17] Bosch M, Carnero M A and Farre L (2010) Information and discrimination in the rental housing market: Evidence from a field experiment Reg Sci Urban Econ 40:11-19.

[18] Bozzoli C and Quintana C (2014) The Weight of the Crisis: Evidence from Newborns in Argentina Rev Econ Stat 96(3): 550-562.

[19] Camacho A (2008) Stress and Birth Weight: Evidence from Terrorist Attacks Am Econ Rev Papers and Proceedings 98 (2): 511-515.

[20] Chen J, Ng E and Wilkins R (1996) The Health of Canada's Immigrants in 94-95. Health Reports 7(4):33-45.

[21] Chiquiar D and Hanson G (2005) International Migration, Self-Selection, and the Distribution of Wages: Evidence form Mexico and the United States J Polit Econ 113(2):239-281.

[22] Chiswick BR. 1978. The Effect of Americanization on the Earnings of Foreign Born Men J Polit Econ 86:897-921.

[23] Chiswick BR (1988) Differences in Education and Earnings across Racial and Ethnic Groups: Tastes, Discrimination and Investment in Child Quality Q J Econ 103: 571-97.

[24] Chiswick BR (1999) Are Immigrants Favorably Self-Selected? Am Econ Rev 89:181-185.

[25] Chiswick BR, Lee YL and Miller PW (2008) Immigrant Selection Systems and Immigrant Health Contemporary Economic Policy 26(4):555-578.

[26] Currie J and Moretti E (2007) Biology as destiny? short- and long-run determinants of intergenerational transmission of birth weight J Labor Econ 25(2): 231-263. 
[27] Currie J, Neidell M and Schneider JF (2009) Air Pollution and Infant Health: Lessons from New Jersey J Health Econ 28(3): 688-703.

[28] Currie J (2009) Healthy, wealthy, and wise: Is there a causal relationship between child health and human capital development J Econ Lit XLVII(1): 87-122.

[29] Deri C (2003) Understanding the Healthy Immigrant Effect in Canada. Unpublished Manuscript.

[30] Donovan J, d'Espaignet E, Metron C and van Ommeren M . eds (1992) Immigrants in Australia: A Health Profile, Australian Institute of Health and Welfare Ethnic Health Series, No 1. Canberra: AGPS.

[31] Fernández-Huertas Moraga J (2011) New Evidence on Emigrant Selection Rev Econ Stat 93(1): 72-96.

[32] Fernández-Huertas Moraga J (2013) Inmigración. ¿Integración sin modelo? edited by Hector Cebolla and Amparo González.

[33] Fernández-Huertas Moraga J (2014) Immigrant Selection over the Business Cycle: The Spanish Boom and the Great Recession. FEDEA Working Paper, 201405 .

[34] Grogger J and Hanson GH (2008) Income Maximization and the Selection and Sorting of International Migrants NBER working paper 13821.

[35] Giuntella O (2012) Why Does the Health of Immigrants Deteriorate? Boston University Mimeo.

[36] Hoynes H, Page M and Stevens AH (2011) Can Targeted Transfers Improve Birth Outcomes? Evidence from the Introduction of the WIC Program Journal of Public Economics 95:813-827.

[37] Jasso G, Massey D, Rosenzweig MD and Smith J (2004) Immigrant Health Selectivity and Acculturation. Chapter 7 in Anderson, Bulatao and Cohen (eds) Critical Perspectives on Racial and Ethnic Differences in Health in Late Life, Committee on Population, National Research Council, Washington DC: The National Academies Press.

[38] King G, Murray CJL, Salomon JA and Tandon A (2004) Enhancing the validity and cross-cultural comparability of measurement in survey research AM Polit Sci Rev 98:191-207. 
[39] Laroche M (2000) Health Status and Health Services Utilization of Canada's Immigrants and Non-Immigrant Population. Canadian Public Policy, University of Toronto Press, 26(1): 51-75.

[40] Macias A (2008) Flujo migratorio de la minoria étnica gitana desde Rumania hacia España. Universidad Pública de Navarra.

[41] McDonald JT (2003) The Health of Immigrants to Canada. mimeo University of New Brunswick.

[42] McKenzie DJ and Rapoport H (2007) Network Effects and the Dynamics of Migration and Inequality: Theory and Evidence from Mexico J Dev Econ 84(1):124.

[43] McKenzie DJ and Rapoport H (2010) Self-Selection Patterns in Mexico-U.S. Migration: The Role of Migration Networks. Rev Econ Stat 92(4): 811-821.

[44] McKenzie DJ, Gibson J and Stillman S (2010) How Important is Selection? Experimental Vs Non-experimental Measures of the Income Gains from Migration J Eur Econ Assoc 4:913-45.

[45] Nanu R, Palicari G, Stativa E and Vitcu A (2006) Starea de nutritie a copilului varsta de pana la 5 ani in Romania. IOMC-Institutul pentru ocrotirea mamei si copilului. Alfred Rusescu. Ministerul Sanatatii Publice, Unicef - reprezentanta in Romania Editura MarLink, ISBN : 973-8411-45-9.

[46] Oreopoulos P, Stabile M, Walld R and Roos LL (2008) Short-, Medium-, and Long-term Consequences of Poor Infant Health Journal of Human Resources 43: 88-138.

[47] Orrenius P and Zavodny M (2005) Did 9/11 worsen the job prospects of Hispanic immigrants?. Working Papers 0508, Federal Reserve Bank of Dallas.

[48] Powles J and Gifford S (1990) How healthy are Australian immigrants? In J. C. Reid and P. Trompf (Eds.), The health of immigrant Australians, pp. 77-107. Sydney: Harcourt, Brace, Jovanovich.

[49] Quintana-Domeque C and Rodenas P (2014) Fear in the Womb: The Effects of Terrorism on Birth Outcomes in Spain. IZA Working Paper 8671.

[50] Royer H (2009) Separated at Girth: US Twin Estimates of the Effects of Birth Weight. American Economic Journal: Applied Economics 1(1): 49-85. 
[51] Rubalcava L, Teruel G, Thomas D and Goldman N (2008) The healthy migrant effect: New findings from the Mexican Family Life Survey American Journal of Public Health 98:78-84.

[52] Spain Vital Statistics. Several years. Spanish Statistical Institute. http://www.cdc.gov/nchs/data_access/Vitalstatsonline.htm\#Downloadable

[53] Stillman S, McKenzie D and Gibson J (2009) Migration and mental health: Evidence from a natural experiment. J Health Econ 28:677-687.

[54] Stillman S, Gibson J and McKenzie D (2012) The Impact of Immigration on Child Health: Experimental Evidence from a Migration Lottery Program Econ Inq 50(1):62-81.

[55] Uitenbroek D and Verhoeff A (2002) Life expectancy and mortality differences between migrant groups living in Amsterdam, the Netherlands. Social Science and Medicine 54:1379-1388.

[56] Voicu A (2005) Employment Dynamics in the Romanian Labor Market: A Markow Chain Monte Carlo Approach J Comp Econ 33(3): 604-639. 
Appendix

\author{
"Insert Table A1 here" \\ "Insert Table A2 here" \\ "Insert Table A3 here" \\ "Insert Table A4 here" \\ "Insert Table A5 here"
}


Tables

Table 1: Births by year and nationality occurred in Spain

\begin{tabular}{|c|c|c|c|c|}
\hline & \multirow[b]{2}{*}{$\begin{array}{c}\text { Total number of } \\
\text { births }\end{array}$} & \multicolumn{3}{|c|}{ By nationality of the mother $(\%)$} \\
\hline & & Immigrant & Ecuadorian & Romanian \\
\hline 2000 & 397,632 & 6.2 & 0.65 & 0.14 \\
\hline 2001 & 406,380 & 8.24 & 1.39 & 0.25 \\
\hline 2002 & 418,846 & 10.55 & 2.01 & 0.50 \\
\hline 2003 & 441,881 & 12.23 & 2.38 & 1.11 \\
\hline 2004 & 454,591 & 13.78 & 2.44 & 1.27 \\
\hline 2005 & 466,371 & 15.07 & 2.13 & 1.48 \\
\hline 2006 & 482,957 & 16.54 & 1.88 & 1.82 \\
\hline 2007 & 492,527 & 18.98 & 1.89 & 2.35 \\
\hline 2008 & 519,779 & 20.81 & 1.84 & 2.62 \\
\hline 2009 & 494,997 & 20.72 & 1.65 & 2.41 \\
\hline 2010 & 486,575 & 20.55 & 1.39 & 2.55 \\
\hline 2011 & 471,999 & 19.51 & 1.13 & 2.46 \\
\hline
\end{tabular}

Note: Birth certificate data. National Statistical Office, Spain. 
Table 2: Birth outcomes by nationality in Spain (2001-2005)

\begin{tabular}{|c|c|c|c|c|c|c|c|}
\hline & Native & Immigrant & Ecuadorian & Romanian & Bulgarian & Colombian & Chinese \\
\hline Birth weight & $\begin{array}{l}3,234.61 \\
(486.19)\end{array}$ & $\begin{array}{l}3,305.20 \\
(519.05)\end{array}$ & $\begin{array}{l}3,295.46 \\
(507.07)\end{array}$ & $\begin{array}{l}3,236.90 \\
(546.33)\end{array}$ & $\begin{array}{l}3,251.81 \\
(506.09)\end{array}$ & $\begin{array}{l}3,309.13 \\
(510.52)\end{array}$ & $\begin{array}{l}3,315.23 \\
(477.99)\end{array}$ \\
\hline Low birth weight & $5.5 \%$ & $5.08 \%$ & $4.85 \%$ & $7.10 \%$ & $5.22 \%$ & $4.72 \%$ & $3.81 \%$ \\
\hline Gestational length (weeks) & $\begin{array}{l}39.16 \\
(1.73)\end{array}$ & $\begin{array}{l}39.17 \\
(1.83)\end{array}$ & $\begin{array}{c}39.15 \\
(13.10)\end{array}$ & $\begin{array}{l}38.91 \\
(2.08)\end{array}$ & $\begin{array}{l}39.16 \\
(1.82)\end{array}$ & $\begin{array}{l}39.06 \\
(1.86)\end{array}$ & $\begin{array}{l}39.34 \\
(1.58)\end{array}$ \\
\hline Preterm birth & $13,88 \%$ & $12,91 \%$ & $13,10 \%$ & $17,67 \%$ & $13,13 \%$ & $13,98 \%$ & $9,90 \%$ \\
\hline $\begin{array}{l}\text { Death within } 24 \text { hours of birth } \\
\text { (per } 1,000 \text { live births) }\end{array}$ & 0,6 & 0,8 & 0,7 & 1,7 & 0,6 & 0,5 & 0,4 \\
\hline Nobs & $1,773,102$ & 233,518 & 41,984 & 16,865 & 3,176 & 21,056 & 8,388 \\
\hline
\end{tabular}

Note: Birth certificate data, National Statistical Office, Spain. Average over the period 2001-2005. Standard deviations in parenthesis. Birth outcomes of $15-49$ aged mothers, excluding multiple births and newborns whose weight was either under 500 grams or above 9,000 grams. 
Table 3: Birth outcomes of immigrants in Spain and natives in Ecuador (2001-2005)

\begin{tabular}{|l|c|c|}
\cline { 2 - 3 } \multicolumn{1}{c|}{} & Immigrants & Natives \\
\hline Birth weight & $\begin{array}{r}3,295.46 \\
(507.07)\end{array}$ & $\begin{array}{l}3,092.58 \\
(469.94)\end{array}$ \\
\hline Low birth weight & $4.85 \%$ & $6.56 \%$ \\
\hline Nobs & 41,984 & 767,499 \\
\hline
\end{tabular}

Note: Birth certificate data, Spain and Ecuador. Information on birth weights for immigrants is taken from the birth certificate data in Spain while that for natives comes from the birth certificate data in Ecuador. The data from Ecuador are censored at 1,000 and 3,750 . The Spanish data have been censored accordingly.

Table 4: Economic cost of migration in Euros by country of origin

\begin{tabular}{|l|c|c|c|c|c|}
\hline Year of arrival & Ecuador & Romania & Colombia & Bulgaria & China \\
\hline $1999-2007$ & $1,591.76 €$ & $398.22 €$ & $1,358.98 €$ & $345.56 €$ & $1,364.99 €$ \\
\hline & $(1,057.31)$ & $(438.03)$ & $(1,007.90)$ & $(488.28)$ & $(1,716.65)$ \\
\hline Nobs & 1,062 & 1,154 & 717 & 267 & 36 \\
\hline
\end{tabular}

Note: The information in this table is collected from the Encuesta Nacional de Inmigrantes 2007. It contains the economic cost of migration per person to move from the country of origin to Spain. It includes transport costs, all types of travel allowances (food, accommodation, etc...), visa and any other type of document, and any other payment related to the migration episode. 
Table 5: Evidence of the Healthy Immigrant Effect

\begin{tabular}{|c|c|c|c|c|c|c|}
\hline & $\begin{array}{c}\text { Birth } \\
\text { weight }\end{array}$ & $\begin{array}{c}\text { Low birth } \\
\text { weight }\end{array}$ & $\begin{array}{c}\text { Gestational } \\
\text { length }\end{array}$ & $\begin{array}{l}\text { Preterm } \\
\text { birth }\end{array}$ & $\begin{array}{l}\text { Normal term } \\
(38-42 \text { weeks })\end{array}$ & $\begin{array}{c}\text { Death } \\
\text { before } 24 \\
\text { hours* }\end{array}$ \\
\hline $\begin{array}{ll}\text { Immigrant } & \text { from } \\
\text { Ecuador } & \end{array}$ & $\begin{array}{c}117.679 * * * \\
{[4.914]}\end{array}$ & $\begin{array}{c}-0.022 * * * \\
{[0.002]}\end{array}$ & $\begin{array}{l}0.038^{* *} \\
{[0.018]}\end{array}$ & $\begin{array}{c}-0.010 * * * \\
{[0.004]}\end{array}$ & $\begin{array}{c}0.010 * * * \\
{[0.004]}\end{array}$ & $\begin{array}{l}-0.020 \\
{[0.024]}\end{array}$ \\
\hline Male & $\begin{array}{c}116.841 * * * \\
{[0.716]}\end{array}$ & $\begin{array}{c}-0.011 * * * \\
{[0.000]}\end{array}$ & $\begin{array}{c}-0.060 * * * \\
{[0.003]}\end{array}$ & $\begin{array}{c}0.010 * * * \\
{[0.001]}\end{array}$ & $\begin{array}{c}-0.010 * * * \\
{[0.001]}\end{array}$ & $\begin{array}{c}0.014 * * * \\
{[0.004]}\end{array}$ \\
\hline Born at a hospital & $\begin{array}{c}19.465 * * * \\
{[5.820]}\end{array}$ & $\begin{array}{c}-0.012 * * * \\
{[0.003]}\end{array}$ & $\begin{array}{c}0.008 \\
{[0.023]}\end{array}$ & $\begin{array}{c}-0.016^{* * *} \\
{[0.004]}\end{array}$ & $\begin{array}{c}0.017 * * * \\
{[0.004]}\end{array}$ & $\begin{array}{c}-0.077 * * * \\
{[0.029]}\end{array}$ \\
\hline $\begin{array}{l}\text { Presence of previous } \\
\text { children }\end{array}$ & $\begin{array}{l}90.701 * * * \\
{[1.507]}\end{array}$ & $\begin{array}{c}-0.029 * * * \\
{[0.001]}\end{array}$ & $\begin{array}{c}-0.032 * * * \\
{[0.006]}\end{array}$ & $\begin{array}{c}-0.020 * * * \\
{[0.001]}\end{array}$ & $\begin{array}{c}0.020 * * * \\
{[0.001]}\end{array}$ & $\begin{array}{c}-0.058 * * * \\
{[0.007]}\end{array}$ \\
\hline $\begin{array}{l}\text { Number of previous } \\
\text { children }\end{array}$ & $\begin{array}{c}5.496 * * * \\
{[0.840]}\end{array}$ & $\begin{array}{c}0.004^{* * *} \\
{[0.000]}\end{array}$ & $\begin{array}{c}-0.061 * * * \\
{[0.003]}\end{array}$ & $\begin{array}{c}0.015^{* * *} \\
{[0.001]}\end{array}$ & $\begin{array}{c}-0.015 * * * \\
{[0.001]}\end{array}$ & $\begin{array}{c}0.003 \\
{[0.004]}\end{array}$ \\
\hline Married & $\begin{array}{c}40.009 * * * \\
{[0.978]}\end{array}$ & $\begin{array}{c}-0.014 * * * \\
{[0.000]}\end{array}$ & $\begin{array}{c}0.059 * * * \\
{[0.004]}\end{array}$ & $\begin{array}{c}-0.011 * * * \\
{[0.001]}\end{array}$ & $\begin{array}{c}0.011 * * * \\
{[0.001]}\end{array}$ & $\begin{array}{c}-0.023 * * * \\
{[0.005]}\end{array}$ \\
\hline Working & $\begin{array}{c}15.971 * * * \\
{[0.839]}\end{array}$ & $\begin{array}{c}-0.006 * * * \\
{[0.000]}\end{array}$ & $\begin{array}{c}0.019 * * * \\
{[0.003]}\end{array}$ & $\begin{array}{c}-0.007 * * * \\
{[0.001]}\end{array}$ & $\begin{array}{c}0.007 * * * \\
{[0.001]}\end{array}$ & $\begin{array}{c}-0.069 * * * \\
{[0.004]}\end{array}$ \\
\hline $\begin{array}{l}\text { Working in a high } \\
\text { skilled occupation }\end{array}$ & $\begin{array}{c}18.451 * * * \\
{[1.016]}\end{array}$ & $\begin{array}{c}-0.008 * * * \\
{[0.000]}\end{array}$ & $\begin{array}{l}-0.005 \\
{[0.004]}\end{array}$ & $\begin{array}{c}-0.007 * * * \\
{[0.001]}\end{array}$ & $\begin{array}{c}0.007 * * * \\
{[0.001]}\end{array}$ & $\begin{array}{c}0.000 \\
{[0.005]}\end{array}$ \\
\hline Years since last birth & $\begin{array}{c}-4.542 * * * \\
{[0.171]}\end{array}$ & $\begin{array}{c}0.002^{* * * *} \\
{[0.000]}\end{array}$ & $\begin{array}{c}0.004 * * * \\
{[0.001]}\end{array}$ & $\begin{array}{c}0.001 * * * \\
{[0.000]}\end{array}$ & $\begin{array}{c}-0.001 * * * \\
{[0.000]}\end{array}$ & $\begin{array}{c}0.000 \\
{[0.000]}\end{array}$ \\
\hline Age dummies & YES & YES & YES & YES & YES & YES \\
\hline Monthly dummies & YES & YES & YES & YES & YES & YES \\
\hline Province dummies & YES & YES & YES & YES & YES & YES \\
\hline Year dummies & YES & YES & YES & YES & YES & YES \\
\hline Constant & $\begin{array}{c}3,014.335^{* * *} \\
{[15.714]}\end{array}$ & $\begin{array}{c}0.110^{* * *} \\
{[0.007]}\end{array}$ & $\begin{array}{c}38.829 * * * \\
{[0.059]}\end{array}$ & $\begin{array}{c}0.174 * * * \\
{[0.011]}\end{array}$ & $\begin{array}{c}0.821 * * * \\
{[0.011]}\end{array}$ & $\begin{array}{c}0.001 \\
{[0.001]}\end{array}$ \\
\hline R-squared & 0.029 & 0.005 & 0.009 & 0.006 & 0.006 & 0.000 \\
\hline Nobs & $1,791,827$ & $1,791,827$ & $1,634,306$ & $1,634,306$ & $1,634,306$ & $1,791,827$ \\
\hline
\end{tabular}

Note: OLS estimates of the linear model in equation (1). The sample includes children born to native and Ecuadorian immigrant mothers in Spain. Sample period 2001-2005. (*) The coefficients in the regression "Death before 24 hours" have been multiplied by 100. 
Table 6: Differences in fertility

\begin{tabular}{|c|c|c|c|c|}
\hline & \multicolumn{2}{|c|}{$\begin{array}{l}\text { Immigrants from } \\
\text { Ecuador } \\
\text { and natives in Spain }\end{array}$} & \multicolumn{2}{|c|}{$\begin{array}{c}\text { Immigrants from } \\
\text { Ecuador } \\
\text { and Romania in Spain }\end{array}$} \\
\hline & Infant & Infant & Infant & Infant \\
\hline $\begin{array}{l}\text { Immigrant from Ecuador } \\
\text { Years since migration }\end{array}$ & $\begin{array}{l}0.013 * * \\
{[0.005]}\end{array}$ & $\begin{array}{c}-0.005 \\
{[0.006]} \\
0.003 \\
{[0.002]}\end{array}$ & $\begin{array}{c}0.036^{* * *} \\
{[0.012]}\end{array}$ & $\begin{array}{c}-0.009 \\
{[0.012]} \\
0.004 \\
{[0.003]}\end{array}$ \\
\hline $\begin{array}{l}\text { Married } \\
\text { Work } \\
\text { Previous children }\end{array}$ & & $\begin{array}{c}0.032 * * * \\
{[0.001]} \\
-0.012 * * * \\
{[0.001]} \\
0.063 * * * \\
{[0.000]}\end{array}$ & & $\begin{array}{c}-0.018 * \\
{[0.011]} \\
-0.145^{*} * * \\
{[0.010]} \\
0.090 * * * \\
{[0.005]}\end{array}$ \\
\hline Age dummies & YES & YES & YES & YES \\
\hline Province dummies & YES & YES & YES & YES \\
\hline Year dummies & YES & YES & YES & YES \\
\hline Constant & & $\begin{array}{c}0.480 * * * \\
{[0.081]}\end{array}$ & & $\begin{array}{c}0.095 \\
{[0.232]} \\
\end{array}$ \\
\hline R-squared & 0.079 & 0.121 & 0.092 & 0.190 \\
\hline Nobs & 436,372 & 436,372 & 4,621 & 4,621 \\
\hline
\end{tabular}

Note: Estimates from the linear probability model in equation (3). In column (1) and (2) the sample includes immigrant women from Ecuador and natives in Spain. In column (3) and (4) the sample is formed by immigrants from Ecuador and Romania. The data are from the Spanish Labor Force Survey, years 2001-2005. 
Table 7: Difference in birth weight of immigrants in Spain and natives in Ecuador

\begin{tabular}{|l|c|c|}
\cline { 2 - 3 } \multicolumn{1}{c|}{} & $\begin{array}{c}\text { Birth } \\
\text { weight }\end{array}$ & $\begin{array}{c}\text { Low birth } \\
\text { weight }\end{array}$ \\
\hline Immigrant from & $\begin{array}{c}178.681^{* * *} \\
{[2.089]}\end{array}$ & $\begin{array}{c}-0.019^{* * *} \\
{[0.001]}\end{array}$ \\
\hline Ecuador & $\begin{array}{c}\text { Male } \\
{[0.919 * * *}\end{array}$ & $\begin{array}{c}-0.011^{* * *} \\
{[0.001]}\end{array}$ \\
\hline $\begin{array}{l}\text { Being born at a } \\
\text { hospital }\end{array}$ & $\begin{array}{c}54.536^{* * *} \\
{[2.238]}\end{array}$ & $\begin{array}{c}0.014^{* * *} \\
{[0.001]}\end{array}$ \\
Presence of \\
previous children & $27.336^{* * *}$ & $-0.010^{* * *}$ \\
Number of & {$[1.328]$} & {$[0.001]$} \\
previous children & $11.698^{* * *}$ & $-0.004^{* * *}$ \\
& {$[0.480]$} & {$[0.000]$} \\
\hline Age dummies & YES & YES \\
Monthly dummies & YES & YES \\
Year dummies & YES & YES \\
\hline Constant & $3,011.141^{* * *}$ & $0.075^{* * *}$ \\
\hline Nobs & 0.026 & $0.003]$ \\
\hline R-squared & 809,483 & 809,483 \\
\hline
\end{tabular}

Note: OLS estimates of the linear model in equation (2). The sample includes children born to native mothers in Ecuador and to Ecuadorian immigrants in Spain. Sample period 2001-2005. 
Table 8: Difference in birth weight of immigrants in Spain and natives in Ecuador Robustness checks

\begin{tabular}{|c|c|c|c|c|}
\hline & $\begin{array}{c}\text { Birth } \\
\text { weight } \\
\text { 2001-2005 }\end{array}$ & $\begin{array}{c}\text { Birth } \\
\text { weight } \\
\text { 2006-2010 }\end{array}$ & $\begin{array}{l}\text { Low birth } \\
\text { weight } \\
2001-2005\end{array}$ & $\begin{array}{l}\text { Low birth } \\
\text { weight } \\
\text { 2006-2010 }\end{array}$ \\
\hline $\begin{array}{l}\text { Immigrant from } \\
\text { Ecuador }\end{array}$ & $\begin{array}{c}179.133 * * * \\
{[2.088]}\end{array}$ & $\begin{array}{c}166.534 * * * \\
{[2.138]}\end{array}$ & $\begin{array}{c}-0.019 * * * \\
{[0.001]}\end{array}$ & $\begin{array}{c}-0.025 * * * \\
{[0.001]}\end{array}$ \\
\hline Male & $\begin{array}{c}67.143 * * * \\
{[0.918]}\end{array}$ & $\begin{array}{c}74.081 * * * \\
{[0.826]}\end{array}$ & $\begin{array}{c}-0.011 * * * \\
{[0.001]}\end{array}$ & $\begin{array}{c}-0.012 * * * \\
{[0.000]}\end{array}$ \\
\hline $\begin{array}{l}\text { Being born at a } \\
\text { hospital }\end{array}$ & $\begin{array}{c}-55.052 * * * \\
{[2.238]}\end{array}$ & $\begin{array}{c}-62.011 * * * \\
{[2.910]}\end{array}$ & $\begin{array}{c}0.014^{* * *} \\
{[0.001]}\end{array}$ & $\begin{array}{c}0.011 * * * \\
{[0.002]}\end{array}$ \\
\hline $\begin{array}{l}\text { Presence of } \\
\text { previous children }\end{array}$ & $\begin{array}{c}27.142 * * * \\
{[1.328]}\end{array}$ & $\begin{array}{c}20.778 * * * \\
{[1.217]}\end{array}$ & $\begin{array}{c}-0.010 * * * \\
{[0.001]}\end{array}$ & $\begin{array}{c}-0.009 * * * \\
{[0.001]}\end{array}$ \\
\hline $\begin{array}{l}\text { Number of } \\
\text { previous children }\end{array}$ & $\begin{array}{c}11.760 * * * \\
{[0.481]}\end{array}$ & $\begin{array}{c}12.563 * * * \\
{[0.459]}\end{array}$ & $\begin{array}{c}-0.004 * * * \\
{[0.000]} \\
\end{array}$ & $\begin{array}{c}-0.003 * * * \\
{[0.000]}\end{array}$ \\
\hline Age dummies & YES & YES & YES & YES \\
\hline Monthly dummies & YES & YES & YES & YES \\
\hline Constant & $\begin{array}{c}3,023.66 * * * \\
{[5.183]}\end{array}$ & $\begin{array}{c}3,034.67 * * * \\
{[4.729]}\end{array}$ & $\begin{array}{c}0.076^{* * *} \\
{[0.003]} \\
\end{array}$ & $\begin{array}{c}0.090 * * * \\
{[0.003]}\end{array}$ \\
\hline R-squared & 0.025 & 0.022 & 0.003 & 0.002 \\
\hline Nobs & 809,483 & $1,068,420$ & 809,483 & $1,068,420$ \\
\hline
\end{tabular}

Note: The estimated models in this table do not contain year fixed effects. This explains the differences with respect to the estimates in Table 7. 
Table 9: Comparing immigrants from Ecuador and Romania in Spain

\begin{tabular}{|c|c|c|c|c|c|c|}
\hline & $\begin{array}{l}\text { Birth } \\
\text { weight }\end{array}$ & $\begin{array}{l}\text { Low birth } \\
\text { weight }\end{array}$ & $\begin{array}{c}\text { Gestational } \\
\text { length }\end{array}$ & $\begin{array}{l}\text { Preterm } \\
\text { birth }\end{array}$ & $\begin{array}{c}\text { Normal term } \\
(38-42 \text { weeks })\end{array}$ & $\begin{array}{c}\text { Death before } \\
24 \text { hours* }\end{array}$ \\
\hline $\begin{array}{l}\text { Immigrant from } \\
\text { Ecuador }\end{array}$ & $\begin{array}{c}60.142 * * * \\
{[5.471]}\end{array}$ & $\begin{array}{c}-0.028 * * * \\
{[0.002]}\end{array}$ & $\begin{array}{c}0.196^{* * *} \\
{[0.021]}\end{array}$ & $\begin{array}{c}-0.040 * * * \\
{[0.004]}\end{array}$ & $\begin{array}{c}0.041 * * * \\
{[0.004]}\end{array}$ & $\begin{array}{c}-0.124 * * * \\
{[0.034]}\end{array}$ \\
\hline Male & $\begin{array}{c}104.773 * * * \\
{[4.229]}\end{array}$ & $\begin{array}{c}-0.007 * * * \\
{[0.002]}\end{array}$ & $\begin{array}{l}-0.002 \\
{[0.016]}\end{array}$ & $\begin{array}{c}0.004 \\
{[0.003]}\end{array}$ & $\begin{array}{l}-0.004 \\
{[0.003]}\end{array}$ & $\begin{array}{c}0.082 \\
{[0.026]}\end{array}$ \\
\hline $\begin{array}{l}\text { Being born at a } \\
\text { hospital }\end{array}$ & $\begin{array}{c}81.505^{* * *} \\
{[25.630]}\end{array}$ & $\begin{array}{c}-0.032 * * * \\
{[0.011]}\end{array}$ & $\begin{array}{c}0.335^{* * *} \\
{[0.101]}\end{array}$ & $\begin{array}{c}-0.052 * * * \\
{[0.018]}\end{array}$ & $\begin{array}{c}0.050 * * * \\
{[0.018]}\end{array}$ & $\begin{array}{l}-0.132 \\
{[0.160]}\end{array}$ \\
\hline $\begin{array}{l}\text { Presence of previous } \\
\text { children }\end{array}$ & $\begin{array}{c}40.785^{* * * *} \\
{[8.815]}\end{array}$ & $\begin{array}{c}-0.010^{* *} \\
{[0.004]}\end{array}$ & $\begin{array}{l}-0.027 \\
{[0.034]}\end{array}$ & $\begin{array}{l}-0.005 \\
{[0.006]}\end{array}$ & $\begin{array}{c}0.004 \\
{[0.006]}\end{array}$ & $\begin{array}{c}0.039 \\
{[0.055]}\end{array}$ \\
\hline $\begin{array}{l}\text { Number of previous } \\
\text { children }\end{array}$ & $\begin{array}{c}17.251 * * * \\
{[3.617]}\end{array}$ & $\begin{array}{l}-0.000 \\
{[0.002]}\end{array}$ & $\begin{array}{c}0.009 \\
{[0.014]}\end{array}$ & $\begin{array}{c}0.003 \\
{[0.003]}\end{array}$ & $\begin{array}{l}-0.003 \\
{[0.003]}\end{array}$ & $\begin{array}{l}-0.022 \\
{[0.022]}\end{array}$ \\
\hline Married & $\begin{array}{c}42.159 * * * \\
{[4.528]}\end{array}$ & $\begin{array}{c}-0.011 * * * \\
{[0.002]}\end{array}$ & $\begin{array}{c}0.143 * * * \\
{[0.017]}\end{array}$ & $\begin{array}{c}-0.021 * * * \\
{[0.003]}\end{array}$ & $\begin{array}{c}0.022 * * * \\
{[0.003]}\end{array}$ & $\begin{array}{c}-0.059 * * \\
{[0.028]}\end{array}$ \\
\hline Working & $\begin{array}{c}10.512 * * \\
{[4.888]}\end{array}$ & $\begin{array}{c}0.001 \\
{[0.002]}\end{array}$ & $\begin{array}{c}-0.040 * * \\
{[0.019]}\end{array}$ & $\begin{array}{c}0.004 \\
{[0.003]}\end{array}$ & $\begin{array}{c}-0.004 \\
{[0.003]}\end{array}$ & $\begin{array}{c}-0.069 * * \\
{[0.030]}\end{array}$ \\
\hline $\begin{array}{l}\text { Working in a high } \\
\text { skilled occupation }\end{array}$ & $\begin{array}{c}1.289 \\
{[13.008]}\end{array}$ & $\begin{array}{l}-0.004 \\
{[0.006]}\end{array}$ & $\begin{array}{c}0.015 \\
{[0.050]}\end{array}$ & $\begin{array}{l}-0.006 \\
{[0.009]}\end{array}$ & $\begin{array}{c}0.006 \\
{[0.009]}\end{array}$ & $\begin{array}{l}-0.013 \\
{[0.081]}\end{array}$ \\
\hline $\begin{array}{l}\text { Years since the last } \\
\text { birth }\end{array}$ & $\begin{array}{c}-0.831 \\
{[0.919]}\end{array}$ & $\begin{array}{c}0.001 \\
{[0.000]}\end{array}$ & $\begin{array}{l}-0.002 \\
{[0.004]}\end{array}$ & $\begin{array}{c}0.001 \\
{[0.001]}\end{array}$ & $\begin{array}{l}-0.001 \\
{[0.001]}\end{array}$ & $\begin{array}{l}-0.006 \\
{[0.006]}\end{array}$ \\
\hline Age dummies & YES & YES & YES & YES & YES & YES \\
\hline Monthly dummies & YES & YES & YES & YES & YES & YES \\
\hline Province dummies & YES & YES & YES & YES & YES & YES \\
\hline Year dummies & YES & YES & YES & YES & YES & YES \\
\hline Constant & $\begin{array}{c}2,873.460 * * * \\
{[60.869]} \\
\end{array}$ & $\begin{array}{c}0.147 * * * \\
{[0.027]}\end{array}$ & \begin{tabular}{|c|}
$38.037 * * *$ \\
{$[0.233]$} \\
\end{tabular} & $\begin{array}{c}0.277 * * * \\
{[0.043]}\end{array}$ & $\begin{array}{c}0.720 * * * \\
{[0.043]}\end{array}$ & $\begin{array}{c}0.000 \\
{[0.004]}\end{array}$ \\
\hline R-squared & 0.029 & 0.006 & 0.017 & 0.016 & 0.016 & 0.003 \\
\hline Nobs & 58,849 & 58,849 & 54,767 & 54,767 & 54,767 & 58,849 \\
\hline
\end{tabular}


Table 10: Comparing different immigrant groups in Spain

\begin{tabular}{|c|c|c|c|c|c|c|}
\hline & $\begin{array}{c}\text { Birth } \\
\text { weight }\end{array}$ & $\begin{array}{c}\text { Low birth } \\
\text { weight }\end{array}$ & $\begin{array}{c}\text { Gestational } \\
\text { length }\end{array}$ & $\begin{array}{l}\text { Preterm } \\
\text { birth }\end{array}$ & $\begin{array}{l}\text { Normal term } \\
(38-42 \text { weeks })\end{array}$ & $\begin{array}{c}\text { Death before } \\
24 \text { hours* }\end{array}$ \\
\hline $\begin{array}{l}\text { Immigrants from } \\
\text { Romania }\end{array}$ & $\begin{array}{c}-52.148 * * * \\
{[5.155]}\end{array}$ & $\begin{array}{c}0.027 * * * \\
{[0.002]}\end{array}$ & $\begin{array}{c}-0.185 * * * \\
{[0.020]}\end{array}$ & $\begin{array}{c}0.038^{* * *} \\
{[0.004]}\end{array}$ & $\begin{array}{c}-0.039^{* * *} \\
{[0.004]}\end{array}$ & $\begin{array}{c}0.121 * * * \\
{[0.030]}\end{array}$ \\
\hline $\begin{array}{l}\text { Immigrants from } \\
\text { Colombia }\end{array}$ & $\begin{array}{c}5.581 \\
{[4.557]}\end{array}$ & $\begin{array}{l}-0.001 \\
{[0.002]}\end{array}$ & $\begin{array}{c}-0.045^{* *} \\
{[0.017]}\end{array}$ & $\begin{array}{l}0.008 * * \\
{[0.003]}\end{array}$ & $\begin{array}{c}-0.008 * * \\
{[0.003]}\end{array}$ & $\begin{array}{l}-0.000 \\
{[0.000]}\end{array}$ \\
\hline $\begin{array}{l}\text { Immigrants from } \\
\text { Bulgaria }\end{array}$ & $\begin{array}{c}-34.189 * * * \\
{[9.730]}\end{array}$ & $\begin{array}{c}0.005 \\
{[0.004]}\end{array}$ & $\begin{array}{c}-0.052 \\
{[0.037]}\end{array}$ & $\begin{array}{c}0.009 \\
{[0.007]}\end{array}$ & $\begin{array}{c}-0.009 \\
{[0.007]}\end{array}$ & $\begin{array}{l}-0.025 \\
{[0.057]}\end{array}$ \\
\hline $\begin{array}{l}\text { Immigrants from } \\
\text { China }\end{array}$ & $\begin{array}{c}-2.482 \\
{[6.365]}\end{array}$ & $\begin{array}{c}-0.006^{* *} \\
{[0.003]}\end{array}$ & $\begin{array}{c}0.176 * * * \\
{[0.025]}\end{array}$ & $\begin{array}{c}-0.022 * * * \\
{[0.005]}\end{array}$ & $\begin{array}{c}0.021 * * * \\
{[0.005]}\end{array}$ & $\begin{array}{c}0.022 \\
{[0.036]}\end{array}$ \\
\hline Additional controls & YES & YES & YES & YES & YES & YES \\
\hline Constant & $\begin{array}{c}2,984.960 * * * \\
{[45.091]}\end{array}$ & $\begin{array}{c}0.111 * * * \\
{[0.020]}\end{array}$ & $\begin{array}{c}38.231 * * * \\
{[0.173]}\end{array}$ & $\begin{array}{c}0.249 * * * \\
{[0.032]}\end{array}$ & $\begin{array}{c}0.751 * * * \\
{[0.032]}\end{array}$ & $\begin{array}{c}0.000 \\
{[0.003]}\end{array}$ \\
\hline R-squared & 0.028 & 0.006 & 0.016 & 0.015 & 0.015 & 0.002 \\
\hline Nobs & 91,469 & 91,469 & 84,207 & 84,207 & 84,207 & 91,469 \\
\hline
\end{tabular}

Note: The sample includes children born to Ecuadorian, Colombian, Bulgarian, Romanian and Chinese immigrant mothers in Spain between 2001 and 2005. The excluded category in estimation are Ecuadorians. Additional controls include: the gender of the child, the set of age dummies for the mother, month, province and year dummies, an indicator for being born at the hospital, the presence of previous children, the number of previous children, a variable for the years since the last birth and an indicator for being married, for working and for working in a high skilled occupation. (*) The coefficients in the regression "Death before 24 hours" have been multiplied by 100 . 


\section{Appendix}

Table A1: Year of arrival by country of origin

\begin{tabular}{|l|c|c|c|c|c|c|c|}
\cline { 2 - 7 } \multicolumn{1}{c|}{} & Immigrants & Ecuador & Morocco & Romania & Colombia & Bulgaria & China \\
\hline before 2000 & 45.30 & 23.32 & 60.43 & 6.67 & 27.84 & 12.07 & 50.41 \\
year 2000 & 8.47 & 23.93 & 6.76 & 7.65 & 19.88 & 12.38 & 8.26 \\
year 2001 & 9.89 & 17.51 & 7.84 & 10.72 & 31.81 & 18.58 & 8.26 \\
year 2002 & 8.82 & 18.88 & 5.57 & 17.92 & 3.78 & 16.41 & 7.44 \\
year 2003 & 8.32 & 10.24 & 6.11 & 17.02 & 2.81 & 13.00 & 6.61 \\
year 2004 & 7.45 & 1.68 & 4.92 & 19.04 & 4.95 & 13.93 & 7.44 \\
year 2005 & 6.18 & 2.06 & 5.14 & 10.79 & 4.36 & 8.05 & 5.79 \\
year 2006 & 5.46 & 2.29 & 3.14 & 10.04 & 4.56 & 5.26 & 3.31 \\
\hline Nobs & 15,465 & 1,308 & 1,850 & 1,334 & 1,031 & 323 & 121 \\
\hline
\end{tabular}

Note: Percentage of immigrants living in Spain per year of arrival. The information is collected from the National Immigrant Survey, 2007. Notice that among immigrants from Ecuador who arrived before 2000, 53.13\% arrived in 1999. This figure was $35.20 \%$ for Colombians. 
Table A2: Aggregate health statistics

\begin{tabular}{|l|c|c|c|}
\hline & Spain & Ecuador & Romania \\
\hline Body mass Index & & & \\
\hline \multicolumn{1}{|c|}{ Male } & 26.6 & 25 & 24.7 \\
\hline \multicolumn{1}{|c|}{ Female } & 26 & 26.4 & 24.9 \\
\hline Life Expectancy in years & 83 & 76 & 75 \\
\hline $\begin{array}{l}\text { Infant Mortality rate } \\
\text { (per 1,000 live births) }\end{array}$ & 6 & 28 & 23 \\
\hline $\begin{array}{l}\text { Child Mortality rate } \\
\text { (per 1,000 live births) }\end{array}$ & 6 & 31.4 & 23.8 \\
\hline Low birth weight probability & 5.5 & 7 & 8 \\
\hline Birth weight & 3,243 & 3,093 & 3,196 \\
& $(490)$ & $(470)$ & $(534)$ \\
\hline
\end{tabular}

Note: World Bank health indicators, several years between 2000-2005. For Spain and Ecuador the information on the birth weight distribution is taken from the birth certificate data employed in the paper for the years 2001-2005. There are no birth certificate data for Romania and the descriptive statistics are obtained from a representative sample in the study of Nanu et al. (2006) for the years 2001 to 2004. Infant Mortality rate is the probability of dying between birth and age 1 per 1000 live births. Child Mortality rate is the probability of dying before age 5 per 1000 live births. 
Table A3: Missing birth weight information in the birth certificate data in Ecuador

\begin{tabular}{|l|c|c|c|c|}
\cline { 2 - 5 } \multicolumn{1}{c|}{} & \multicolumn{2}{c|}{$2001-2005$} & \multicolumn{2}{c|}{$2006-2010$} \\
\cline { 2 - 5 } & Nobs & $\begin{array}{c}\text { \% missing } \\
\text { information } \\
\text { Eirth weight }\end{array}$ & Nobs & $\begin{array}{c}\text { \% missing } \\
\text { information } \\
\text { birth weight }\end{array}$ \\
No education & 11,130 & $66.27 \%$ & 22,929 & $44.04 \%$ \\
Primary & 606,080 & $44.66 \%$ & 726,234 & $25.13 \%$ \\
Higher & 438,754 & $25.49 \%$ & 266,560 & $15.18 \%$ \\
\hline Area: & 985,657 & $33.64 \%$ & $1,049,838$ & $17.17 \%$ \\
Urban & 253,470 & $57.54 \%$ & 236,014 & $41.98 \%$ \\
Rural & 30,929 & $65.80 \%$ & 33,714 & $41.03 \%$ \\
\hline Periphery & & & & $89.96 \%$ \\
\hline Place born: & 586,866 & $24.24 \%$ & 698,508 & $10.23 \%$ \\
Public hospital & 353,930 & $17.96 \%$ & 403,731 & $6.49 \%$ \\
Private hospital & 329,231 & $88.70 \%$ & 217,327 & $89.95 \%$ \\
Other (house) & $1,270,056$ & $39.20 \%$ & $1,319,566$ & $22.21 \%$ \\
\hline Total & & & & \\
\hline
\end{tabular}

Note: Birth certificate data, Ecuador. 
Table A4: Socio-economic characteristics of female natives and immigrants in Spain

\begin{tabular}{|c|c|c|c|c|c|c|}
\hline & Native & Ecuador & Romania & Colombia & Bulgaria & China \\
\hline Age & $\begin{array}{l}38.97 \\
{[6.67]}\end{array}$ & $\begin{array}{l}32.61 \\
{[7.21]}\end{array}$ & $\begin{array}{l}31.93 \\
{[7.31]}\end{array}$ & $\begin{array}{c}34.67 \\
{[7.31]}\end{array}$ & $\begin{array}{c}34.89 \\
{[7.64]}\end{array}$ & $\begin{array}{c}36.62 \\
{[7.53]}\end{array}$ \\
\hline Year of arrival & & $\begin{array}{c}2000 \\
{[1.99]}\end{array}$ & $\begin{array}{c}2001 \\
{[2.33]}\end{array}$ & $\begin{array}{c}2000 \\
{[2.95]}\end{array}$ & $\begin{array}{c}2001 \\
{[1.98]}\end{array}$ & $\begin{array}{c}1996 \\
{[6.13]}\end{array}$ \\
\hline $\begin{array}{l}\text { Education } \\
\text { Less than HS } \\
\text { HS graduates } \\
\text { More than HS }\end{array}$ & $\begin{array}{l}53.08 \% \\
27.38 \% \\
19.54 \%\end{array}$ & $\begin{array}{l}47.23 \% \\
40.54 \% \\
12.23 \%\end{array}$ & $\begin{array}{l}30.68 \% \\
55.22 \% \\
14.10 \%\end{array}$ & $\begin{array}{l}36.97 \% \\
48.10 \% \\
14.94 \%\end{array}$ & $\begin{array}{l}34.54 \% \\
40.51 \% \\
24.95 \%\end{array}$ & $\begin{array}{c}65.43 \% \\
25.93 \% \\
8.64 \%\end{array}$ \\
\hline Work & $55.61 \%$ & $71.34 \%$ & $65.12 \%$ & $61.81 \%$ & $62.47 \%$ & $80.25 \%$ \\
\hline $\begin{array}{l}\text { Low skilled } \\
\text { occupation }\end{array}$ & $61.47 \%$ & $97.66 \%$ & $96.10 \%$ & $89.65 \%$ & $95.56 \%$ & $76.15 \%$ \\
\hline Married & $83.95 \%$ & $68.10 \%$ & $72.14 \%$ & $56.82 \%$ & $76.33 \%$ & $88.27 \%$ \\
\hline With kids & $63.61 \%$ & $69.59 \%$ & $45.61 \%$ & $60.11 \%$ & $45.42 \%$ & $61.11 \%$ \\
\hline Number of kids & $\begin{array}{c}1.54 \\
{[0.65]}\end{array}$ & $\begin{array}{c}1.67 \\
{[0.84]}\end{array}$ & $\begin{array}{c}1.33 \\
{[0.61]}\end{array}$ & $\begin{array}{c}1.56 \\
{[0.67]}\end{array}$ & $\begin{array}{c}1.32 \\
{[0.47]}\end{array}$ & $\begin{array}{c}1.77 \\
{[0.86]}\end{array}$ \\
\hline Nobs & 433,560 & 2,812 & 1,809 & 2,705 & 469 & 162 \\
\hline
\end{tabular}

Note: The sample is restricted to women 16-49 years old, who are head of households or the partner. Standard deviations in brackets. Sample period: 2001-2005. Spanish Labor Force Survey. 
Table A5: Differences in fertility across immigrant groups

\begin{tabular}{|c|c|c|}
\hline & Infant & Infant \\
\hline Immigrant from Romania & $\begin{array}{c}-0.043 * * * \\
{[0.011]}\end{array}$ & $\begin{array}{c}-0.006 \\
{[0.011]}\end{array}$ \\
\hline Immigrants from Colombia & $\begin{array}{c}-0.023 * * \\
{[0.009]}\end{array}$ & $\begin{array}{c}-0.017^{*} \\
{[0.009]}\end{array}$ \\
\hline Immigrants from Bulgaria & $\begin{array}{c}-0.085 * * * \\
{[0.017]}\end{array}$ & $\begin{array}{c}-0.053 * * * \\
{[0.017]}\end{array}$ \\
\hline Immigrants from China & $\begin{array}{c}-0.069 * * * \\
{[0.027]}\end{array}$ & $\begin{array}{c}-0.059 * * \\
{[0.026]}\end{array}$ \\
\hline Years since migration & & $\begin{array}{c}0.001 \\
{[0.002]}\end{array}$ \\
\hline Married & & $\begin{array}{c}-0.001 \\
{[0.008]}\end{array}$ \\
\hline Work & & $\begin{array}{c}-0.121 * * * \\
{[0.007]}\end{array}$ \\
\hline Previous children & & $\begin{array}{c}0.088 * * * \\
{[0.004]}\end{array}$ \\
\hline Age dummies & YES & YES \\
\hline Province dummies & YES & YES \\
\hline Year dummies & YES & YES \\
\hline Constant & $\begin{array}{c}-0.072 \\
{[0.234]}\end{array}$ & $\begin{array}{c}-0.095 \\
{[0.222]}\end{array}$ \\
\hline R-squared & 0.073 & 0.167 \\
\hline Observations & 7,957 & 7,957 \\
\hline
\end{tabular}

Note: Estimates from the linear probability model in equation (3). The sample includes immigrant women from China, Ecuador, Romania, Bulgaria and Colombia. Sample period 2001-2005. Spanish Labor Force Survey. 